\title{
The secretion and effect of inhibin A, activin A and follistatin on first-trimester trophoblasts in vitro
}

\author{
C Bearfield, E Jauniaux, N Groome ${ }^{1}$, I L Sargent ${ }^{2}$ and S Muttukrishna \\ Department of Obstetrics and Gynaecology, RFUC Medical School, 86-96 Chenies Mews, London WC1E 6HX, UK, ${ }^{1}$ School of Biological and Molecular \\ Sciences, Oxford Brookes University, Headington, Oxford, UK and ${ }^{2}$ Nuffield Department of Obstetrics and Gynaecology, University of Oxford, \\ John Radcliffe Hospital, Oxford, UK,
}

(Correspondence should be addressed to S Muttukrishna; Email: s.muttukrishna@ucl.ac.uk)

\begin{abstract}
Objective: The objectives of this study were to investigate the effect of activin A and follistatin on firsttrimester cytotrophoblast invasion in culture and to study the secretion of inhibin A, activin A and follistatin by these cells in vitro.

Design and methods: Cytotrophoblasts were isolated from human placental chorionic villous tissue obtained from $6-8,8-10$ and 10-12 weeks gestation. Cells were cultured for 3 days on cell-culture inserts coated with gelatine for invasion studies and in 24-well culture plates for secretion studies. The effects of activin A $(10 \mathrm{ng} / \mathrm{ml})$, follistatin $(100 \mathrm{ng} / \mathrm{ml})$, interleukin $1 \beta$ (IL-1 $\beta ; 10 \mathrm{ng} / \mathrm{ml})$ and epidermal growth factor (EGF; $10 \mathrm{ng} / \mathrm{ml}$ ) on cytotrophoblast invasion were investigated using a nonradioactive invasion assay. Secretion of inhibin A, activin A and follistatin in the presence of EGF, IL-1 $\beta$, activin A and follistatin were measured using in-house ELISAs.

Results and conclusion: Activin A, follistatin and EGF had a significant stimulatory effect on cytotrophoblast invasion from $6-10$ weeks gestation. IL-1 $\beta$ had a significant stimulatory effect at $8-10$ weeks and a significant inhibitory effect on invasion at $10-12$ weeks gestation. Follistatin also had a significant inhibitory effect on invasion at 10-12 weeks gestation. In the secretion study, activin A secretion at 8-10 weeks was significantly stimulated by IL-1 $\beta$ and EGF. At 10-12 weeks, follistatin and EGF had a significant inhibitory effect on activin A secretion. Follistatin secretion was significantly increased in the presence of IL-1 $\beta$ at $6-8$ weeks gestation. Inhibin A secretion was not significantly altered by EGF, IL-1 $\beta$, activin A and follistatin. These results show that activin A promotes invasion of first-trimester cytotrophoblasts until 10 weeks gestation. There is a difference in the control of secretion of these proteins dependent on the gestation, suggesting that there is a tight regulation in the function of first-trimester trophoblasts depending on the gestational age.
\end{abstract}

European Journal of Endocrinology 152 909-916

\section{Introduction}

Human placentation is characterized by the migration of specialized epithelial cells termed cytotrophoblasts, which differentiate along two different pathways. In one pathway, cytotrophoblasts fuse and form a multinucleated syncytium (the syncytiotrophoblast) that covers the floating chorionic villi. The syncytiotrophoblast is involved in the exchange of gases, nutrients and waste between the mother and the fetus. In the second pathway, a subpopulation of cytotrophoblast stem cells differentiates into invasive trophoblasts. During this differentiation process, aggregates of cytotrophoblasts attach and then invade the uterine wall to anchor the fetus to the mother. These extravillous cytotrophoblasts subsequently invade the inner third of the myometrium and the arterioles that supply this area. The interaction of invasive cytotrophoblasts with the maternal environment is complex and involves the production of multiple growth factors, cytokines, enzymes and binding proteins to regulate invasion (1). Many growth factors and cytokines, such as epidermal growth factor (EGF) and interleukin 1 (IL-1) have been shown to be involved in trophoblast differentiation (1). In particular, transforming growth factor $\beta$ (TGF $\beta$ ) has been shown to reduce proliferation and invasion of human cytotrophoblasts in culture $(2,3)$.

Inhibins, activins and follistatin are glycoproteins of the TGF $\beta$ superfamily and it has been shown that the placenta is a major source of these in early pregnancy. The placenta expresses inhibin and activin subunit genes and activin receptor genes throughout 
pregnancy $(4,5)$ and high levels of inhibin A (6), activin A (7) and follistatin (8) have also been found in maternal blood in pregnancy. Maternal circulating levels of these proteins have been shown to be higher in abnormal pregnancies such as pre-eclampsia $(9,10)$. In pre-eclampsia there is inadequate invasion of the trophoblasts into the spiral arteries and abnormal blood supply to the placenta (11). Activin A and inhibin A levels in the maternal circulation are higher in patients who subsequently develop pre-eclampsia as early as 12 weeks gestation, suggesting these abnormal levels may be a consequence of poor placental development. A previous study with first-trimester explants has shown that activin A could promote invasion of the extravillous cytotrophoblasts (12).

In pre-eclampsia (where there is poor invasion) there is increased levels of activin A that might act to promote invasion. However, follistatin is an activin-binding protein and will regulate the availability of activin binding to its receptors. Inhibin also binds to activin receptors with lower affinity. Therefore, increased levels of inhibin A in pre-eclampsia might also restrict the biological action of activin $\mathrm{A}$ on the differentiation of cytotrophoblasts.

Term trophoblasts in culture syncytialize and secrete inhibin A and activin A constitutively and inflammatory cytokines stimulate the secretion of these proteins from syncytiotrophoblasts (13). Inhibin/activin subunit proteins and mRNA were identified in the early-pregnancy placenta (4). There is, however, no evidence for the secretion of these dimeric proteins by isolated first-trimester trophoblasts.

First-trimester chorionic villi contains both villous and extravillous cytotrophoblasts (14), which can differentiate into syncytiotrophoblasts in vitro (15) or invasive trophoblasts (16), depending on the culture conditions.

Different methods have been used to quantify invasion in matrigel systems. Previous studies have either used filters sputter-coated with gold palladium in a scanning electron microscope to produce photographs to analyse the surface area of the filter covered by invasive cells (17-19), confocal microscopy to count the number of fluorescently labelled cells (20) or light microscopy with haematoxylin eosin staining (21). Tritiated thymidine incorporation of cells migrating to the outer side of the membrane has also been used as an invasion assay (22). Since the microscopic methods are subjective and the radioactive methods are laborious we have adapted a commercial quantitative nonradioactive invasion assay method for this purpose.

It is evident from previous studies that implantation and early placentation are inflammatory processes (23). We have shown that at term inflammatory cytokines stimulate syncytiotrophoblast secretion of inhibin A and activin A. The aims of this study were firstly to investigate the secretion of these proteins in terms of the effects of EGF and IL-1 $\beta$ on first-trimester trophoblast secretion of inhibin A, activin A and follistatin.
The autocrine/paracrine effects of activin A and follistatin on inhibin A, follistatin and activin A secretion were also investigated. Secondly we investigated the effects of activin $A$ and follistatin on trophoblast invasion using a non-radioactive invasion assay. EGF and IL-1 $\beta$, which have been shown previously to stimulate trophoblast invasion in vitro, were used as positive controls (1).

\section{Materials and methods}

\section{Placental tissue}

Placental tissue samples were collected from uncomplicated first-trimester terminations of pregnancy between 6 and 12 weeks gestation. The tissue was washed in sterile PBS (Life Technologies) to remove any blood contamination and placed in sterile magnesium- and calcium-free Hanks balanced salt solution (HBSS; Life Technologies) with gentamicin $(50 \mathrm{mg} / \mathrm{ml})$ and amphotericin B $(50 \mathrm{mg} / \mathrm{ml})$ for transportation to the laboratory.

Gestational age was determined from the first day of the last menstrual period and confirmed by ultrasound measurement of the fetal crown-rump length in ongoing pregnancies. Written consent was obtained from each woman after receiving complete information on the procedure. Approval for this study was obtained from the joint UCL/UCLH Ethics Committees on the ethics of human research.

The chorionic villous tissue was removed, minced and washed thoroughly using HBSS. Cytotrophoblast cells were isolated using a modified method of Fisher et al. (24). The tissues were weighed and digested in calcium- and magnesium-free HBSS containing $5 \mathrm{mg}$ protease type XIV at $1 \mathrm{mg} / \mathrm{ml}$ (Sigma), $2.5 \mathrm{mg}$ collagenase type IV at $0.5 \mathrm{mg} / \mathrm{ml}$ and $50 \mu \mathrm{l}$ DNase type I at $5 \mathrm{mg} / \mathrm{ml}$ per $\mathrm{g}$ of tissue in a shaking water bath at $37^{\circ} \mathrm{C}$ using a digestion of three or four steps lasting 10 minutes each.

Dispersed cells in the supernatant were filtered through a $100 \mu \mathrm{m}$ strainer and collected and washed in $10 \mathrm{ml}$ Dulbecco's Modified Eagle's Medium (DMEM; Life Technologies; plus $50 \mathrm{mg} / \mathrm{ml}$ gentamicin/amphotericin B and 20\% fetal bovine serum).

After centrifugation $(200 \mathrm{~g}$ for $10 \mathrm{~min})$, the pellet was reconstituted in $5 \mathrm{ml} 5 \%$ Percoll, layered over a $5-70 \%$ continuous Percoll gradient and centrifuged for $20 \mathrm{~min}$ at $18^{\circ} \mathrm{C}$ and $220 \mathrm{~g}$. The cytotrophoblast cells were removed from the middle of the gradient, washed with supplemented DMEM and resuspended in ice-cold PBS/1\% BSA. The cytotrophoblasts were enriched by treating them with immunomagnetic Dynabeads (Dynal UK, Bromborough, Cheshire, UK) coated with CD45 (Dynal UK) and Thy-1 (Serotec, Oxford, UK) at $4{ }^{\circ} \mathrm{C}$ for $30 \mathrm{~min}$ to remove leucocytes and stromal cells respectively. Contaminating cells were removed by placing the tubes containing the cells on a magnetic rack. After depletion, the cytotrophoblast cell suspension was washed and resuspended in DMEM/50 mg/ml gentamicin/amphotericin B/20\% 
fetal bovine serum. Cell viability was determined by Trypan Blue exclusion.

The purity of the cell preparation was determined by flow cytometry after their purification with Dynabeads as described by Linton et al. (25) using an anti-cytokeratin 7 antibody (K7).

\section{Experimental design}

Two separate studies were performed. The first examined the effects of these factors upon secretion of inhibin A, activin $A$ and follistatin by first-trimester trophoblast cells in culture and the second examined the effects of activin A, inhibin A, follistatin, EGF and IL-1 $\beta$ on the invasive properties of the cells.

\section{Secretion of inhibin, activin $A$ and follistatin}

The cells were plated on gelatin-coated 12-well tissueculture plates at a concentration of 250000 cells in $500 \mu \mathrm{l}$ DMEM with serum-free supplement per well. Time-dependent constitutive secretion of human chorionic gonadotrophin (hCG), inhibin A, activin A and follistatin was measured to study the effect of duration of culture on the secretion of these proteins in vitro.

Cultures were treated with IL-1 $\beta(10 \mathrm{ng} / \mathrm{ml})$, EGF $(10 \mathrm{ng} / \mathrm{ml})$, activin A $(10 \mathrm{ng} / \mathrm{ml})$ and follistatin $(100 \mathrm{ng} / \mathrm{ml})$ and incubated at $37^{\circ} \mathrm{C}$ in a $5 \% \mathrm{CO}_{2}$ atmosphere for $72 \mathrm{~h}$.

After the incubation period, cell-culture medium was collected and assayed for inhibin A, activin A and follistatin secretion (if cells were treated with activin, then follistatin and inhibin were measured, and if they were treated with follistatin then activin A and inhibin were measured). All experiments were repeated with placental cells obtained from six to ten individual patients at every gestational window studied.

\section{Invasion assay}

A commercial invasion-assay system from Chemicon (Chandlers Ford, Hampshire, UK) was modified and used. $12 \mu \mathrm{m}$ Millicell culture-plate inserts were coated with $1 \%$ gelatin and placed in a 12 -well tissue-culture plate. Into the outer chamber $500 \mu \mathrm{l}$ DMEM/serumfree supplement (Sigma)/gentamicin/amphotericin B was added. To this medium IL-1 $\beta(10 \mathrm{ng} / \mathrm{ml})$, EGF $(10 \mathrm{ng} / \mathrm{ml})$, activin A $(10 \mathrm{ng} / \mathrm{ml})$ and follistatin (100 ng/ml; R\&D Systems, Oxon, UK) were added on day 1 of the culture. The concentrations and time in culture were chosen after preliminary experiments with varying doses and incubation times. The supplemented serum-free DMEM was used as a control medium.

The cytotrophoblast cells were dispensed onto the cell-culture inserts at a concentration of 250000 cells (according to manufacturer's instructions) in $300 \mu \mathrm{l}$ DMEM plus serum-free supplement (Sigma). Cultures were incubated at $5 \% \mathrm{CO}_{2}$ in a tissue-culture incubator. Each treatment was carried out in triplicate in every culture.

After $72 \mathrm{~h}$ incubation the cell-culture inserts were removed from the tissue-culture plate and washed gently by immersion in sterile PBS. Any invading cells would have migrated through the micropores on the cell-culture insert and attached to the bottom of the membrane. Using a cotton-tipped swab non-invading cells were removed gently from the upper surface of the cell-culture insert.

\section{Cell staining procedure}

$500 \mu \mathrm{l}$ of the staining solution (Diffquik; Roche, Bucks, UK) was placed into a tissue-culture plate. Invasive trophoblast cells (confirmed by cytokeratin 7 staining) on the lower surface of the membrane were stained by placing the inserts in the wells containing the Diffquik solution for $20 \mathrm{~min}$. The inserts were then washed by dipping in distilled water several times to remove excess dye and allowed to air dry. Invasion of the micropore membrane was confirmed visually by inverted light microscopy prior to colorimetric quantification.

The inserts were then placed in a new tissue-culture plate containing $300 \mu \mathrm{l} 10 \%$ acetic acid per well and incubated at room temperature for $10 \mathrm{~min}$, which lyses the cells and releases the dye into the medium. $150 \mu \mathrm{l}$ of the dye/solute mixture per sample was placed in a 96-well plate and read at $540 \mathrm{~nm}$ on an ELISA plate reader. Each sample was read in duplicate and the mean was taken. Control gelatin-coated inserts with no cells were stained and used as blanks for nonspecific binding. Initial experiments were carried out with matrigel-coated membranes as recommended by the manufacturer (Roche Diagnostics) but this was then changed to gelatin-coated membranes as they produced lower background staining (non-specific binding) and colour development upon extraction.

The mean absorbance at $540 \mathrm{~nm}$ of the untreated cell cultures was regarded as $100 \%$ invasion. Each cell culture treated with activin A $(10 \mathrm{ng} / \mathrm{ml})$, follistatin (100 ng/ml), IL-1 $\beta(10 \mathrm{ng} / \mathrm{ml})$ or EGF $(10 \mathrm{ng} / \mathrm{ml})$ was then normalized against controls and converted to a percentage of invasion compared with the untreated control cells. All experiments were repeated with placental cells obtained from six to ten individual patients at every gestational window studied.

\section{Hormone assays}

Inhibin A Inhibin A was measured using a two-site ELISA that has been previously validated for human granulosa cell culture medium by Muttukrishna et al. (26). The minimum detection limit of this assay was $1 \mathrm{pg} / \mathrm{ml}$ (National Institute for Biological Standards, Potters Bar, Herts, UK). The results were expressed as a percentage of the control. Intra- and inter-assay coefficients of variation were 4.5 and $5.1 \%$ respectively. 
Activin A Activin A was measured using a two-site ELISA specific for total activin A (follistatin bound + free activin A) as described by Muttukrishna et al. (26). The detection limit of this assay for human recombinant activin A (Genentech, San Francisco, CA, USA) was $50 \mathrm{pg} / \mathrm{ml}$. The results were expressed as a percentage of the control. Intra- and inter-assay coefficients of variation were 8.5 and $9.8 \%$ respectively.

Follistatin Follistatins were measured using a two-site ELISA developed by Evans et al. (27). The sensitivity of this assay was $20 \mathrm{pg} / \mathrm{ml}$. The results were expressed as a percentage of the control. Intra- and inter-assay coefficients of variation were 6.8 and $9.15 \%$ respectively.

hCG hCG was measured by an immunoradiometric assay (IRMA) using a commercial kit purchased from EURO DPC (Llanberis, Wales, UK). Intra- and inter-assay coefficients of variation were $<10 \%$. The minimum detection limit of the assay was $0.03 \mathrm{mIU} / \mathrm{ml}$.

\section{Statistical analysis}

Data are presented as percentages of the control (control values $=100 \%$ ). Time-dependent studies were analysed using one-way analysis of variance (ANOVA) and the effect of cytokines and proteins on invasion and secretion were analysed using Student's t-test (GraphPad Prism, San Diego, CA, USA). Normalized percentage data were used for statistical analysis. The mean from the four control wells/treatment in each culture was considered as $100 \%$. The treated sample values were normalized against this control value to give a relative percentage. These relative percentage values from different cultures were used for statistical analysis. The mean absolute concentrations are given in the legends. A $P$ value of $<0.05$ was considered to be of statistical significance.

\section{Results}

The viability of the isolated cells was always $>95 \%$ and they were $86.1 \pm 10.6 \%$ positive for cytokeratin 7 , confirming that the majority were cytotrophoblasts.

\section{Secretion study}

Cytotrophoblasts secreted activin A, follistatin, inhibin A and hCG in culture (Fig. 1). Although there was a significant decrease in hCG secretion on day 2 and 3 compared with day $1(P<0.001)$, inhibin A, activin $A$ and follistatin secretion were not significantly altered with increasing time in culture.

Activin A secretion was not significantly altered when cytotrophoblasts from 6-8 weeks gestation were cultured for 3 days in the presence of follistatin, EGF and IL-1 $\beta$ compared with the controls (Table 1 ). However, activin A secretion was significantly stimulated when
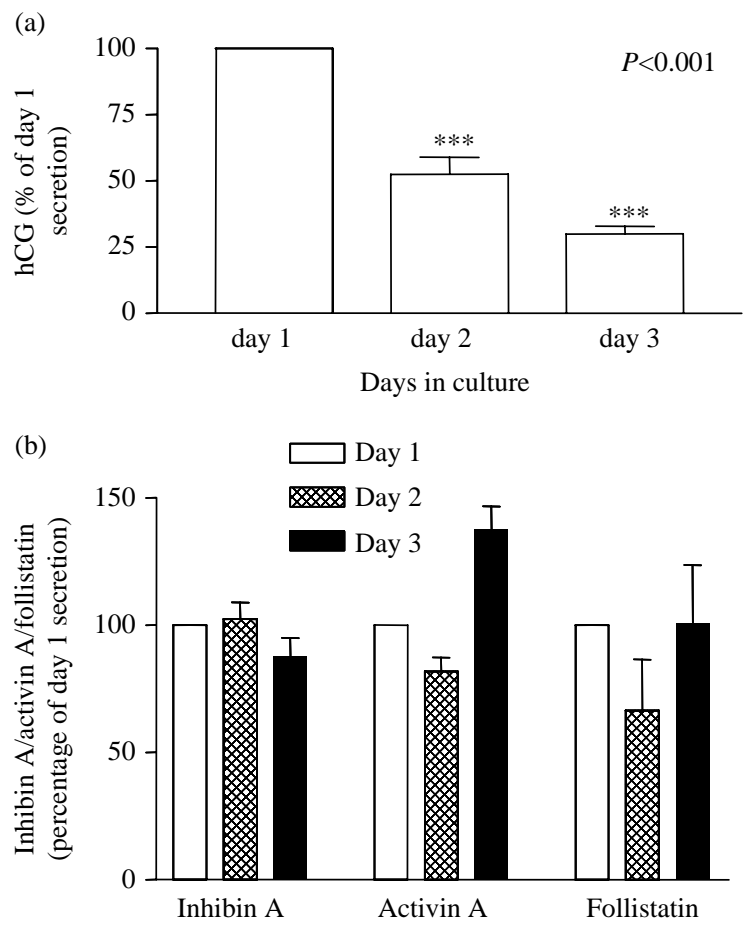

Figure 1 Time-dependent release of (a) hCG and (b) inhibin A, activin $A$ and follistatin expressed as percentage of control $\left(100 \%=\right.$ day 1 release; means \pm S.E.M.). ${ }^{\star \star \star} P<0.001$ (ANOVA). $100 \% \mathrm{hCG}=104 \pm 17 \mathrm{IU} / \mathrm{ml}, 100 \%$ inhibin $A=1.05 \pm 0.1 \mathrm{ng} / \mathrm{ml}$, $100 \%$ activin $\mathrm{A}=5.96 \pm 0.1 \mathrm{ng} / \mathrm{ml}$ and $100 \%$ follistatin $=$ $1.45 \pm 0.15 \mathrm{ng} / \mathrm{ml}$.

cytotrophoblasts from $8-10$ weeks gestation were cultured in the presence of EGF $(180 \% ; P<0.001)$ and IL-1 $\beta(141 \% ; P=0.01)$ compared with the controls. In contrast, by 10-12 weeks gestation there was a significant inhibitory effect on activin A secretion in the presence of follistatin $(79 \% ; P<0.05)$ and EGF $(81 \%$; $P<0.05)$ compared with controls.

At $6-8$ weeks, follistatin secretion was significantly increased in the presence of IL- $1 \beta(130 \% ; P<0.05)$

Table 1 Effect of follistatin, EGF and IL-1 $\beta$ on the secretion of activin A ( 3 days) expressed as percentage of control at $6-8$ weeks, $8-10$ weeks and $10-12$ weeks. $100 \%=$ untreated controls. Absolute concentration of activin A ( $100 \%$ value) for $6-8$ weeks $=26.5 \pm 3 \mathrm{ng} / \mathrm{ml}, 8-10$ weeks $=23.3 \pm 4 \mathrm{ng} / \mathrm{ml}$ and $10-12$ weeks $=9.6 \pm 1.6 \mathrm{ng} / \mathrm{ml}$.

\begin{tabular}{|c|c|c|c|}
\hline & \multicolumn{3}{|c|}{$\begin{array}{l}\text { Percentage secretion compared } \\
\text { with control }\end{array}$} \\
\hline & $6-8$ weeks & $8-10$ weeks & $\overline{10-12 \text { weeks }}$ \\
\hline Control & $100 \%$ & $100 \%$ & $100 \%$ \\
\hline Follistatin $(100 \mathrm{ng} / \mathrm{ml})$ & $132 \pm 23 \%$ & $179 \pm 38 \%$ & $\begin{array}{l}\quad 79 \pm 9 \% \\
(P<0.05)\end{array}$ \\
\hline EGF (10 ng/ml) & $272 \pm 95 \%$ & $\begin{array}{r}180 \pm 17 \% \\
(P<0.001)\end{array}$ & $\begin{array}{r}81 \pm 8 \% \\
(P<0.05)\end{array}$ \\
\hline $\mathrm{IL}-1 \beta(10 \mathrm{ng} / \mathrm{ml})$ & $199.7 \pm 81 \%$ & $\begin{array}{l}141.5 \pm 24 \% \\
(P=0.01)\end{array}$ & $108.7 \pm 16 \%$ \\
\hline
\end{tabular}


Table 2 Effect of activin A, EGF and IL-1 $\beta$ on the secretion of follistatin (3 days) expressed as percentage of control at 6-8 weeks, $8-10$ weeks and $10-12$ weeks. $100 \%=$ untreated controls. Absolute concentration of follistatin (100\% value) for $6-8$ weeks $=2.9 \pm 0.34 \mathrm{ng} / \mathrm{ml}, 8-10$ weeks $=3.9 \pm 0.5 \mathrm{ng} / \mathrm{ml}$ and $10-12$ weeks $=7.1 \pm 0.86 \mathrm{ng} / \mathrm{ml}$.

\begin{tabular}{lccc}
\hline & \multicolumn{3}{c}{ Percentage secretion compared } \\
& \multicolumn{3}{c}{ with control } \\
\cline { 2 - 4 } & $6-8$ weeks & $8-10$ weeks & $10-12$ weeks \\
\hline Control & $100 \%$ & $100 \%$ & $100 \%$ \\
Activin A $(10 \mathrm{ng} / \mathrm{ml})$ & $140 \pm 94 \%$ & $159 \pm 34 \%$ & $179 \pm 47 \%$ \\
EGF $(10 \mathrm{ng} / \mathrm{ml})$ & $73.4 \pm 9.8 \%$ & $152 \pm 27 \%$ & $99 \pm 12 \%$ \\
& $(P<0.05)$ & & \\
IL-1 $\beta(10 \mathrm{ng} / \mathrm{ml})$ & $130 \pm 12 \%$ & $97 \pm 10 \%$ & $119 \pm 18 \%$ \\
& $(P<0.05)$ & & \\
\hline
\end{tabular}

and decreased in the presence of EGF $(73 \% ; P<0.05)$ compared with the controls, whereas activin A did not have a significant effect. Follistatin secretion was not significantly altered when first-trimester cytotrophoblasts from $8-10$ and $10-12$ weeks gestation were cultured for 3 days in the presence of activin $A$, follistatin, EGF and IL-1 $\beta$ compared with the controls (Table 2).

Inhibin A secretion was not significantly altered when first-trimester cytotrophoblasts from $6-8,8-10$ and 10-12 weeks gestation were cultured for 3 days in the presence of activin A, follistatin, EGF and IL-1 $\beta$ compared with the controls (Table 3).

\section{Invasion assay}

First-trimester trophoblasts $(6-10$ weeks $)$ were cultured for 24,48 and $72 \mathrm{~h}$ to test the effect of culture period on the number of cells invading through the membrane. Increasing numbers of cells invaded through the chamber with time, as shown by an increase in the absorbance at $540 \mathrm{~nm}$ (Fig. 2).

At 6-8 weeks gestation there was a significant increase in the number of cells invading in the presence of activin A $(184 \pm 37.18 \% ; P=0.001)$, follistatin $(245 \pm 33.9 \% ; P=0.001)$ and EGF $(220.7 \pm 40 \%$;

Table 3 Effect of activin A, follistatin, EGF and IL-1 $\beta$ on the secretion of activin $A$ ( 3 days) expressed as percentage of control at $6-8$ weeks, $8-10$ weeks and $10-12$ weeks. $100 \%=$ untreated controls. Absolute concentration of inhibin A (100\% value) for $6-8$ weeks $=3.2 \pm 0.23 \mathrm{ng} / \mathrm{ml}, 8-10$ weeks $=1.1 \pm 0.16 \mathrm{ng} / \mathrm{ml}$ and $10-12$ weeks $=2.76 \pm 0.8 \mathrm{ng} / \mathrm{ml}$.

\begin{tabular}{|c|c|c|c|}
\hline & \multicolumn{3}{|c|}{$\begin{array}{l}\text { Percentage secretion compared } \\
\text { with control }\end{array}$} \\
\hline & $6-8$ weeks & $8-10$ weeks & $10-12$ weeks \\
\hline Control & $100 \%$ & $100 \%$ & $100 \%$ \\
\hline Activin A (10 ng/ml) & $92 \pm 12.6 \%$ & $99.9 \pm 11.6 \%$ & $128 \pm 34 \%$ \\
\hline Follistatin $(100 \mathrm{ng} / \mathrm{ml})$ & $130 \pm 33 \%$ & $120 \pm 16 \%$ & $98 \pm 10 \%$ \\
\hline EGF (10 ng/ml) & $153.6 \pm 50 \%$ & $157.8 \pm 31 \%$ & $102 \pm 9 \%$ \\
\hline $\mathrm{IL}-1 \beta(100 \mathrm{ng} / \mathrm{ml})$ & $135 \pm 30 \%$ & $106 \pm 9 \%$ & $101 \pm 6 \%$ \\
\hline
\end{tabular}

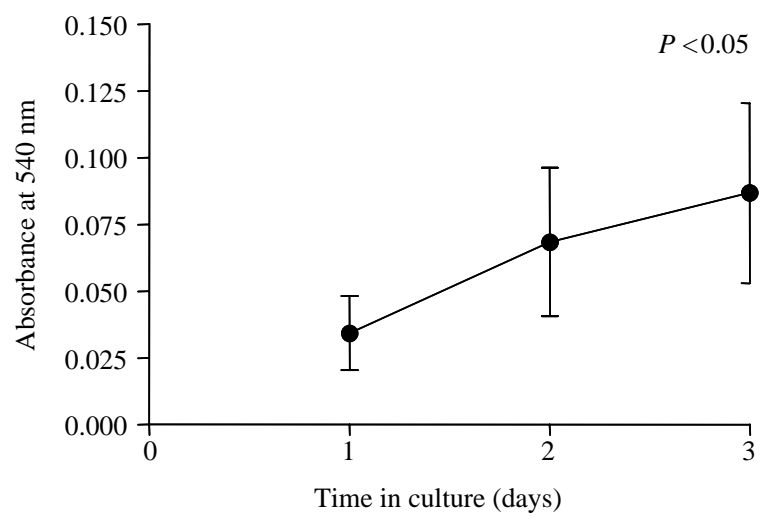

Figure 2 Time-dependent changes in the absorbance at $540 \mathrm{~nm}$ of cells invading through the membrane. Means \pm S.E.M. for absorbance in three separate experiments are shown.

$P=0.001)$ compared with the control cells (Fig. 3). IL-1 $\beta$ had no significant effect $(157 \pm 67 \%)$ at this gestation. At 8-10 weeks, there was a significant increase in the number of cells invading in the presence of activin A $(131.7 \pm 13.2 \% ; \quad P<0.05), \quad$ follistatin $(179.8 \pm 11.96 \% ; P=0.002)$ and EGF $(120 \pm 10 \%$; $P<0.05)$ compared with the controls. IL-1 $\beta$ had no significant effect at this stage $(110 \pm 9.8 \%$; Fig. 3). However, by $10-12$ weeks, activin A $(99 \pm 10 \%)$ and EGF $(115 \pm 32 \%)$ no longer had a significant effect on invasion. Furthermore, IL-1 $\beta(64.3 \pm 9.7 \% ; P<0.05)$ and follistatin $(70.8 \pm 8.4 \% ; P=0.001)$ had inhibitory effects on invasion of cytotrophoblasts compared with the controls (Fig. 3). Recombinant inhibin A

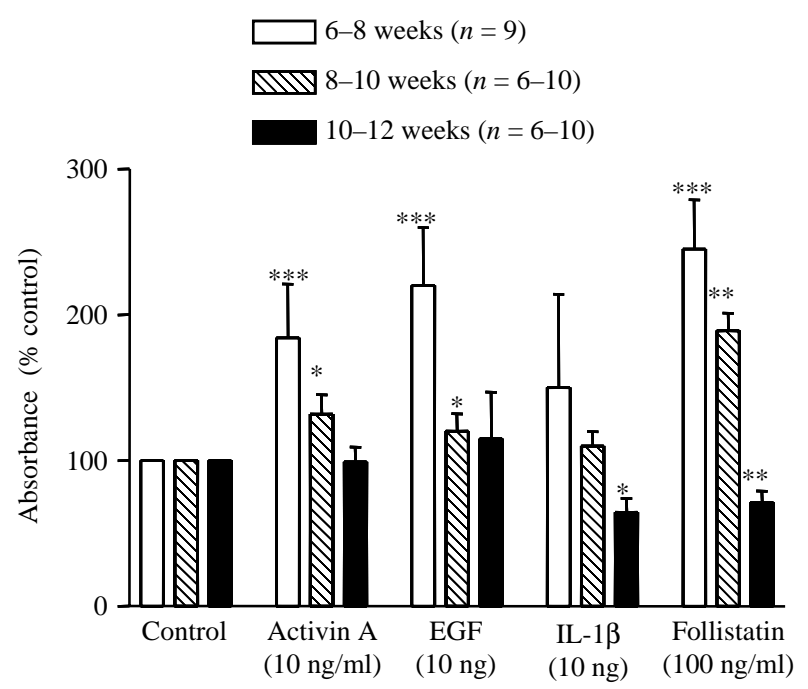

Figure 3 Effects of activin A (10 ng/ml), EGF (10 ng/ml), IL-1 $\beta$ $(10 \mathrm{ng} / \mathrm{ml})$ and follistatin $(100 \mathrm{ng} / \mathrm{ml})$ on cytotrophoblast invasion at $6-8(n=9), 8-10(n=6-10)$ and $10-12$ weeks $(n=6-10)$ gestation. Means \pm S.E.M. for percentages of control absorbance values are plotted. $100 \%=$ untreated cell-invasion absorbance. Student's $t$-test was carried out to test the differences between the control and the treatment groups: ${ }^{\star} P<0.05$, ${ }^{\star \star} P<0.01$, $\star \star \star P<0.001$. 
had no effect on cytotrophoblast invasion at any stage of gestation (data not shown).

\section{Discussion}

Several studies have investigated the factors controlling first-trimester trophoblast invasion. Different methods including microscopic techniques (17-20) and radioactive invasion assays (22) have been used to quantify invasion on a matrigel system. In this study, we have utilized a modified commercial non-radioactive invasion assay, which is much easier than the previous cell-counting methods. Using this invasion assay we have shown that the number of cells invading through the membrane was increased with increasing number of days in culture. It is possible that trophoblast differentiation along the invasive pathway is a result of the balanced action of growth factors and cytokines acting in both an autocrine and paracrine manner. Insulinlike growth factor II (IGF-II), IGF-I-binding protein I (IGFBP-I), IL-1 $\beta$ and EGF have all been shown to promote cytotrophoblast invasion whereas platelet-derived growth factors (PDGF-AA and PDGF-BB), vascular endothelial growth factor (VEGF), placental growth factor (PGF) and tumour necrosis factor $\alpha$ (TNF $\alpha$ ) had no effect on invasion $(17,18,28-30)$. Transforming growth factor $\beta$ (TGF- $\beta$ ) was reported to have no effect by Bass et al. (17), whereas Irving \& Lala (28) reported it to have a negative effect on invasion.

In this study, the effects of EGF and IL-1 $\beta$ were consistent to other published studies on invasion. The molecular pathways through which these molecules act are as yet unclear. However, IL-1 $\beta$ has shown to stimulate trophoblast secretion of type IV collagenase, matrix metalloproteinase 9 (MMP-9) and MMP activity (18). It is suggested that cytokines and growth factors may control trophoblast invasiveness through regulation of adhesion molecules or that matrix components may be responsible for insufficient trophoblast invasion in diseases characterized by poor placentation $(31,32)$.

In this study, we have further investigated this effect of activin A on isolated first-trimester cytotrophoblasts obtained at $6-8,8-10$ and $10-12$ weeks gestation. Our data are consistent with the results of Caniggia et al. (12) and shows that activin A increases the number of cells invading through the membrane at 6-10 weeks gestation. However, activin A has no effect on these cells at 10-12 weeks gestation, suggesting that activin may have an important role on placental invasion but that the effect is limited to early in the first trimester coinciding with the luteo-placental shift in early pregnancy. The magnitude of the stimulatory effect of activin A was greater at $6-8$ weeks $(\sim 80 \%)$ compared with $8-10$ weeks $(\sim 30 \%)$, suggesting that, as the gestational age increased, the capacity of activin to stimulate invasion diminished. When first-trimester (5-7 weeks) placental chorionic villous explants were cultured in vitro, activin A stimulated the outgrowth of cytotrophoblasts into the surrounding matrix (12), an effect that was reversed by follistatin. It was also shown that activin A stimulates invasion of cytotrophoblasts from first-trimester (5-7 weeks) explants by inducing MMP-2 and MMP-9 expression. Caniggia et al. (12) also reported that follistatin alone had no effect on explants. In our study, when follistatin was added on its own to isolated cytotrophoblasts it had a significant stimulatory effect on invasion at 6-10 weeks. However, at 10-12 weeks it had an inhibitory effect, suggesting a tight control of cytotrophoblast invasion after 10 weeks gestation. When follistatin was incubated with activin $A$ and added to the cells the effect of activin A was neutralized and inhibin A did not have an effect on invasion (data not shown), consistent with Caniggia et al.'s study (12). EGF also had no effect on invasion at $10-12$ weeks whereas IL-1 $\beta$ had an inhibitory effect.

Insufficient trophoblast invasion contributes to the development of pre-eclampsia whereas unrestricted invasion is associated with pre-malignant conditions such as invasive mole and choriocarcinoma. Therefore, it is essential for factors promoting this invasion to regulate the process in a tightly controlled manner. It is evident that higher concentrations of activin A are secre ted from cells obtained at 6-8 weeks compared with $10-12$ weeks gestation whereas follistatin secretion is higher from cells obtained from 10-12 weeks gestation compared with 6-8 weeks. Exogenous addition of follistatin also had an inhibitory effect on cells obtained at 10-12 weeks gestation and a stimulatory effect on invasion of cells obtained from 6-10 weeks gestation, suggesting that cytotrophoblasts may self-regulate the action of these proteins. There is evidence that activin A upregulates type I activin receptor mRNA levels in human immortalized extravillous trophoblast cells (33).

Our previous in vivo studies have shown that in patients who subsequently develop severe pre-eclampsia at $<34$ weeks gestation, activin A levels are raised in maternal circulation as early as $8-12$ weeks. We speculate that placental activin A secretion is increased in these patients as a compensatory mechanism because of poor invasion of the placenta. The secretion studies showed that inhibin A, activin A and follistatin are secreted by the cytotrophoblasts in culture at $6-8$, 8-10 and 10-12 weeks gestation. Previous studies have shown that immunoreactive inhibin (ir-inhibin), inhibin A and activin A were secreted by term trophoblasts in culture $(13,34-36)$. This is the first study to report the secretion of inhibin A, activin A and follistatin by first-trimester trophoblasts. In this study, we found that with increasing time in culture, hCG secretion decreased and activin A, follistatin and inhibin A secretion were not significantly affected. Activin A secretion was stimulated by EGF and IL-1 $\beta$ at 8-12 weeks and follistatin at $10-12$ weeks in this study consistent with the term cytotrophoblast cultures (13), suggesting that these molecules had the same 
effect on activin A secretion from cytotrophoblasts in the first trimester and syncytiotrophoblasts at term.

Follistatin secretion by term trophoblasts syncytializing in culture was below the detection limit of the assay (13). However, in this study, as the cells differentiated into invasive trophoblasts, high concentrations of follistatin were secreted. Higher levels of follistatin were also secreted with increasing gestation. This suggests that follistatin may have an independent role in early pregnancy. It has been reported that follistatin promotes angiogenesis (37). We could speculate that follistatin secreted by these cells may be involved in the formation of the spiral arteries and establishment of the placental circulation. Inhibin A secretion by first-trimester cytotrophoblasts was not significantly affected by activin A, follistatin, EGF or IL-1 $\beta$, whereas inhibin A secretion by term trophoblasts was stimulated by EGF and IL-1 $\beta$ (13) as cells syncytialized in culture.

In summary, this study shows that activin A, follistatin and inhibin A are secreted by isolated first-trimester trophoblasts in culture. We have shown that activin A and follistatin promotes firsttrimester cytotrophoblast invasion at $6-10$ weeks and activin A secretion is stimulated by EGF and IL-1 $\beta$. Activin A and follistatin may play a role in the differentiation of first-trimester trophoblasts and placental development in early pregnancy.

\section{Acknowledgements}

This project was funded by a Wellcome Trust project grant (no. 059743).

\section{References}

1 Morrish D. Functional regulation of human trophoblast differentiation. Journal of Reproductive Immunology 199839 179-195.

2 Graham CH \& Lala PK. Mechanism of control of trophoblast invasion in situ. Journal of Cell Physiology 1991148 228-234.

3 Graham CH \& Lala PK. Mechanism of placental invasion of the uterus and their control. Biochemistry and Cell Biology 199270 $867-874$.

4 Petraglia F, Garuti GC, Calza L, Roberts V, Giardino L, Genazzani AR, Vale $W$ \& Meunier $H$. Inhibin subunits in human placenta: localization and messenger ribonucleic acid levels during pregnancy. American Journal of Obstetrics and Gynecology $1991165750-758$.

5 Peng C, Ohno T, Koh LY, Chen VT \& Leung PC. Human ovary and placenta express messenger RNA for multiple activin receptors. Life Science 199964 983-994.

6 Muttukrishna S, George L, Fowler PA, Groome NP \& Knight PG. Measurement of serum concentrations of inhibin-A (alpha-beta A dimer) during human pregnancy. Clinical Endocrinology 1995 42 391-397.

7 Muttukrishna S, Fowler PA, George L, Groome NP \& Knight PG. Changes in peripheral serum levels of 'total' activin A during the human menstrual cycle and pregnancy. Journal of Clinical Endocrinology and Metabolism 199681 3328-3334.

8 Fowler PA, Evans LW, Groome NP, Templeton A \& Knight PG. A longitudinal study of maternal serum inhibin-A, inhibin-B,
activin-A, activin- $\mathrm{AB}$, pro-alphaC and follistatin during pregnancy. Human Reproduction 199813 3530-3536.

9 Muttukrishna S, Knight PG, Groome NP, Redman CWG \& Ledger WL. Inhibin A and activin A: new endocrine markers for pre-eclampsia? Lancet 1997349 1285-1288.

10 Muttukrishna S, North RA, Morris J, Schellenberg JC, Taylor RS, Asselin J, Ledger W, Groome N \& Redman CW. Serum inhibin and activin A are elevated prior to the onset of pre-eclampsia. Human Reproduction 200015 1640-1645.

11 Burton GJ \& Jauniaux E. Pathophysiology of histological changes in early pregnancy loss. Placenta 20053 114-123.

12 Caniggia I, Lye SJ \& Cross JC. Activin is a local regulator of human cytotrophoblast cell differentiation. Endocrinology $1997 \mathbf{1 3 8}$ 3976-3986.

13 Mohan A, Asselin J, Sargent IL, Groome NP \& Muttukrishna S. Effect of cytokines and growth factors on the secretion of inhibin $\mathrm{A}$, activin A and follistatin by term placental villous trophoblasts in culture. European Journal of Endocrinology 2001145 505-511.

14 Sacks GP, Clover LM, Bainbridge DR, Redman CW \& Sargent IL. Flow cytometric measurement of intracellular Th1 and Th2 cytokine production by human villous and extravillous cytotrophoblast. Placenta 200122 550-559.

15 Guibourdenche J, Frendo JL, Pidoux G, Bertin G, Luton D, Muller F, Porquet D \& Evain-Brion D. Expression of pregnancy associated plasma protein A (PAPP-A) during human villous trophoblasts differentiation in vitro. Placenta $200324532-539$.

16 Fisher SJ \& Damsky CH. Human cytotrophoblast invasion. Seminars in Cell Biology 19934 183-188.

17 Bass KE, Morrish D, Roth I, Bhardwaj D, Taylor R \& Zhou Y. Human cytotrophoblast invasion is up regulated by epidermal growth factor: evidence that paracrine factors modify this process. Developmental Biology 1994164 550-561.

18 Librach CL, Feigenbaum SL, Bass KE, Cui TY, Verastas N, Sadovsky Y, Quigley JP, French DL \& Fisher SL. Interleukin-1 beta regulates human cytotrophoblast metalloproteinase activity and invasion in vitro. Journal of Biological Chemistry 1994269 17125-17131.

19 Damsky CH, Librach C, Lim KH, Fitzgerald ML, McMaster MT, Janatpour M, Zhou Y, Logan SK \& Fisher SJ. Integrin switching regulates normal trophoblast invasion. Development $1994 \mathbf{1 2 0}$ 3657-3666.

20 Genbacev O, Joslin R, Damsky CH, Polliotti BM \& Fisher SJ. Hypoxia alters early gestation human cytotrophoblast differentiation/invasion in vitro and models the placental defects that occur in pre eclampsia. Journal of Clinical Investigation 199697 540-550.

21 Shimonovitz S, Hurwitz A, Dushnik M, Anteby E, Geva-Eldar T \& Yagel S. Developmental regulation of the expression of 72 and $92 \mathrm{kd}$ type IV collagenases in human trophoblast: a possible mechanism for control of trophoblast invasion. American Journal of Obstetrics and Gynaecology $1994171832-838$.

22 Graham CH, Connelly I, MacDougall JR, Kerbel RS, Stetler-Stevenson WG \& Lala PK. Resistance of malignant trophoblast cells to both the anti-proliferative and anti-invasive effects of transforming growth factor-beta. Experimental Cell Research 1994 214 93-99.

23 Redman CW \& Sargent IL. Pre eclampsia, the placenta and the maternal systemic inflammatory response - a review. Placenta 200324 Suppl S21-S27.

24 Fisher SJ, Sutherland A, Moss L, Hartman L, Crowley E, Bernfield M, Calarco P \& Damsky C. Adhesive interactions of murine and human trophoblast cells. Trophoblast Research 1990 4 115-138.

25 Linton EA, Rodriguez-Linares B, Rashid-Doubell F, Ferguson DJ \& Redman CW. Caveolae and caveolin-1 in human term villous trophoblast. Placenta 200324 745-757.

26 Muttukrishna S, Groome NP \& Ledger WL. Gonadotrophic control of secretion of dimeric inhibins and activin A by human granulosa-luteal cells in vitro. Journal of Assisted Reproduction and Genetics 199714 566-574. 
27 Evans LW, Muttukrishna S \& Groome NP. Development, validation and application of an ultra sensitive two-site enzyme immunoassay for human follistatin. Journal of Endocrinology $1998 \mathbf{1 5 6}$ $275-282$.

28 Irving JA \& Lala PK. Functional role of cell surface integrins on human trophoblast cell migfration: regulation by TGF- $\beta$, IGF-II and IGFBP-I. Experimental and Cell Research 1995217 419-427.

29 Athanassiades A \& Lala PK. Role of placenta growth factor (PIGF) in human extravillous trophoblast proliferation, migration and invasiveness. Placenta 199819 465-473.

30 Athanassiades A, Hamilton GS \& Lala PK. Vascular endothelial growth factor stimulates proliferation but not migration or invasiveness in human extravillous trophoblast. Biology of Reproduction $199859643-654$.

31 Damsky CH, Fitzgerald ML \& Fisher SJ. Distribution patterns of extracellular matrix components and adhesion receptors are intricately modulated during first trimester cytotrophoblast differentiation along the invasive pathway in vivo. Journal of Clinical Investigation $199289210-222$.

32 Zhou Y, Damsky CH, Chiu K, Roberts JH \& Fisher SJ. Pre eclampsia is associated with abnormal expression of adhesion molecules by invasive cytotrophoblasts. Journal of Clinical Investigation 1993 91 950-960.
33 Chen VT, Peng C \& Leung PC. Activin A up-regulates type I activin receptor mRNA levels in human immortilised extravillous trophoblast cells. Reproductive Biology and Endocrinology 20031 $1-9$.

34 Qu J, Ying S-Y \& Thomas K. Inhibin production and secretion in human placental cells cultured in vitro. Obstetrics and Gynaecology $199279705-712$.

35 Mather JP, Woodruff TK \& Krummen LA. Paracrine regulation of reproductive function by inhibin and activin. Proceedings of the Society for Experimental Biology and Medicine 1992201 1-15.

36 Keelan J, Song Y \& France JT. Comparative regulation of inhibin, activin and human chorionic gonadotropin production by placental trophoblast cells in culture. Placenta 199415 803-818.

37 Kozian DH, Ziche M \& Augustin HG. The activin-binding protein follistatin regulates autocrine endothelial cell activity and induces angiogenesis. Laboratory Investigation $1997 \mathbf{7 6} 267-276$.

Received 15 September 2004

Accepted 22 March 2005 